\title{
Antibiotic therapy for Crohn's disease: A review
}

\author{
Simon Lal MD PhD, A Hillary Steinhart MD FRCPC
}

\begin{abstract}
S Lal, AH Steinhart. Antibiotic therapy for Crohn's disease: A review. Can J Gastroenterol 2006;20(10):651-655.

Increasing evidence suggests that gut bacteria play a pathogenic role in Crohn's disease (CD), providing a rationale for the use of antibiotics in the primary treatment of the disease. While there are data to suggest that antibiotics may be effective in treating active luminal, particularly colonic, and/or perianal CD, evidence for their use in these settings is hampered by the lack of well-designed, adequately powered, placebo-controlled trials. Furthermore, although nitroimidazole antibiotics have been shown to reduce postoperative recurrence following ileocolonic resection, their use is limited by side effects. There is a current need for rigorous multicentre studies looking into the role of antibiotics in treating perianal and luminal $\mathrm{CD}$, as well as a need for the large-scale assessment of novel antibiotics, with low systemic absorption, which may improve patient tolerance.
\end{abstract}

Key Words: Antibiotics; Crohn's disease; Inflammatory bowel disease; Perianal Crohn's disease; Postoperative Crohn's disease

\section{Le traitement de la maladie de Crohn par les antibiotiques : examen de la documentation}

De plus en plus de preuves tendent à montrer que la flore intestinale joue un rôle pathogène dans l'apparition de la maladie de Crohn (MC), ce qui justifierait le recours aux antibiotiques pour le traitement principal de la maladie. Même si des données semblent montrer l'efficacité des antibiotiques dans le traitement de la MC évolutive, luminale, touchant le côlon ou la région péri-anale, le manque d'essais comparatifs avec placebo, bien conçus et suffisamment puissants limitent leur utilisation dans ce contexte. De plus, même si les antibiotiques nitro-imidazolés réduisent les risques de réapparition de la maladie après une résection iléo-colique, leurs effets indésirables limitent également leur utilisation. Aussi faut-il, d'une part, mener des études multicentriques, rigoureuses, sur le rôle des antibiotiques dans le traitement de la MC luminale ou péri-anale et, d'autre part, entreprendre une évaluation à grande échelle de nouveaux antibiotiques ayant une faible absorption générale, ce qui en améliorerait la tolérabilité.
$\mathrm{W}$ hile antibiotics have a definite role in treating specific, episodic or persisting bacterial infections that may complicate Crohn's disease (CD), such as intra-abdominal abscesses or small intestinal bacterial overgrowth, their therapeutic ability in controlling the primary disease is not fully established and has proven to be controversial (1-3).

Bacteria have long been implicated as potential contributing factors in the pathogenesis of CD and two schools of thought currently exist: $C D$ results from infection with a specific organism and atypical mycobacteria have received the most attention in this regard (4), or the disease arises as a consequence of an abnormal immune response to commensal enteric flora (5). A number of studies have explored the use of traditional antimycobacterial agents to treat CD with limited success to date $(6,7)$, and the pathogenic role of mycobacterium remains unresolved (4). However, there is increasing evidence that $\mathrm{CD}$ results from an imbalance between protective and harmful enteric organisms (called 'dysbiosis' [5]), leading to the initiation and then persistence of intestinal inflammation in genetically susceptible individuals with altered immune responses. Such evidence may provide a rationale for the use of antibiotics as primary therapy in CD.

\section{ROLE OF GASTROINTESTINAL BACTERIA IN THE PATHOGENESIS OF CD}

The role of commensal bacteria in the etiology of $\mathrm{CD}$ has gathered momentum over recent years, with evidence derived from both animal models and human studies. Genetically engineered germ-free rodents, for example, fail to develop experimental enterocolitis unless colonized with normal gut flora (8-11) and significantly, such models of intestinal inflammation display therapeutic responses to antibiotics (12-15). The observation that disease activity is attenuated by diversion but exacerbated by restoration of the fecal stream in patients with CD lends further support to the concept that luminal contents, possibly enteric flora, play a pathogenic role $(16,17)$. Additionally, patients with inflammatory bowel disease (IBD) display increased concentrations of mucosal bacteria, both anaerobic (Bacteroides) and aerobic (Enterobacteriaceae) species, compared with control subjects, with increasing bacterial concentrations associated with more severe disease (18). While the latter commensal organisms may be harmful, the finding that there is a reduction in protective organisms, such as Bifidobacterium and Lactobacillus, in patients with IBD $(19,20)$, adds support to the aforementioned concept of dysbiosis in CD (5).

For commensal organisms to be a causal factor in CD, host susceptibility is required to generate an abnormal inflammatory response to the normal intestinal flora. Therefore, it is relevant that patients with IBD display loss of immunological tolerance to commensal bacteria, with enhanced cell-mediated (21) and humoral (22) responses. Recent evidence strongly implicates host genetic susceptibility as a key factor in predisposing not only to such abnormal immune responses, but also to impaired mucosal bacterial clearance. It has been suggested, for example, that polymorphisms in the nucleotide-binding

Inflammatory Bowel Disease Centre, Mount Sinai Hospital, Toronto, Ontario

Correspondence: Dr A Hillary Steinhart, Mount Sinai Hospital, Room 445, 600 University Avenue, Toronto, Ontario M5G 1 X5.

Telephone 416-586-5121, fax 416-586-5121, e-mail hsteinhart@mtsinai.on.ca

Received for publication December 20, 2005. Accepted January 31, 2006 
TABLE 1

Principal antibiotic trials in luminal Crohn's disease

\begin{tabular}{|c|c|c|c|c|c|}
\hline References & Year & $\mathbf{n}$ & Antibiotic & Duration & Summary of results \\
\hline Blichfeldt et al (30) & 1978 & 22 & Metronidazole $250 \mathrm{mg}$ qid & 2 months & $\begin{array}{l}\text { Symptomatic improvement in six patients with colonic } \\
\text { disease }\end{array}$ \\
\hline Ursing et al (32) & 1982 & 78 & Metronidazole $400 \mathrm{mg}$ bid & 4 months & Slightly more effective than sulfasalazine \\
\hline Ambrose et al (33) & 1985 & 72 & $\begin{array}{l}\text { Metronidazole } 400 \mathrm{mg} \mathrm{bid} \mathrm{and} / \mathrm{or} \\
\text { cotrimoxazole } 960 \mathrm{mg} \text { bid }\end{array}$ & 1 month & No benefit versus placebo \\
\hline Sutherland et al (34) & 1991 & 105 & $\begin{array}{l}\text { Metronidazole } 10 \mathrm{mg} / \mathrm{kg} / \text { day or } \\
20 \mathrm{mg} / \mathrm{kg} / \text { day }\end{array}$ & 16 weeks & $\begin{array}{l}\text { Reduction in Crohn's disease Activity Index versus } \\
\text { placebo particularly with colonic disease, but no } \\
\text { difference in remission rates }\end{array}$ \\
\hline Colombel et al (38) & 1999 & 40 & Ciprofloxacin $1 \mathrm{~g} /$ day & 6 weeks & Equally effective as mesalamine in inducing remission \\
\hline Arnold et al (39) & 2002 & 47 & Ciprofloxacin $500 \mathrm{mg}$ bid & 6 months & Reduction in Crohn's disease Activity Index versus placebo \\
\hline Prantera et al (40) & 1996 & 41 & $\begin{array}{l}\text { Metronidazole } 250 \mathrm{mg} \text { qid } \\
\text { and ciprofloxacin } 500 \mathrm{mg} \text { bid }\end{array}$ & 12 weeks & $\begin{array}{l}\text { Remission rate of } 46 \% \text { with antibiotic regimen versus } 63 \% \\
\text { with methylprednisone }\end{array}$ \\
\hline Greenbloom et al (42) & 1998 & 72 & $\begin{array}{l}\text { Metronidazole } 250 \mathrm{mg} \text { tid } \\
\text { and ciprofloxacin } 500 \mathrm{mg} \text { bid }\end{array}$ & 10 weeks & $\begin{array}{l}\text { Uncontrolled study: } 68 \% \text { remission rate, more likely if } \\
\text { colonic disease }\end{array}$ \\
\hline
\end{tabular}

bid Twice a day; tid Three times a day; qid Four times a day

oligomerization domain 2/caspase recruitment domain 15 gene, which has been found in a subset of patients with CD $(23,24)$, may contribute to disease pathogenesis secondary to impaired clearance of invasive bacteria (25).

\section{ANTIBIOTIC TREATMENT OF CD}

The putative role that bacteria play in the etiology of $\mathrm{CD}$ clearly provides a sound rationale for the use of antibiotics in the primary treatment of the disease. There are existing data suggesting that antibiotics may be efficacious in the treatment of active luminal and/or perianal disease, as well as aid in preventing postoperative disease recurrence. The mechanism of action of antibiotics in these clinical settings remains to be fully elucidated; while it is likely that they act in a conventional antimicrobial manner to reduce the proportion of harmful bacterial species or to limit bacterial invasion and/or bacterial secretory products (26), some of the antibiotics used in CD may also exert direct immunomodulatory effects (27-29).

\section{Antibiotic therapy in active luminal CD}

A number of antibiotic regimens have been evaluated in the treatment of active luminal CD (Table 1), and have either been directed against a specific pathogen such as an atypical mycobacterium or have been used in an attempt to modulate normal gut flora.

For many years, most of the interest in antibiotics was centred on metronidazole, a nitroimidazole antibiotic with an antimicrobial spectrum of activity against anaerobes. Blichfeldt et al (30) compared the effect of metronidazole against placebo in an early double-blind crossover study in 22 patients; although no overall clinical benefit was observed, six patients with only colonic involvement displayed both symptomatic and biochemical improvement. In the Swedish cooperative CD study, metronidazole (400 mg taken twice a day) was compared to sulphasalazine (1.5 g taken twice a day) for the treatment of active $\mathrm{CD}$ using a double-blind crossover design (31,32). A total of 78 patients were randomly assigned and followed for up to eight months (two four-month periods). During the first four-month treatment period, reductions in the scores of the CD Activity Index (CDAI) were similar in both groups, although patients taking metronidazole had significantly greater reductions in plasma orosomucoid levels and greater increases in hemoglobin levels. However, only 10 of $40(25 \%)$ patients in the metronidazole group achieved quiescent disease at the end of the first treatment period, compared with 15 of $38(39.5 \%)$ patients in the sulfasalazine group. Patients who had not experienced a reduction in their CDAI scores in the first part of the study experienced a reduction in CDAI during the second portion of the study if they were crossed over to metronidazole, but not to sulfasalazine. It was concluded that metronidazole was slightly more effective than sulfasalazine in the treatment of active $\mathrm{CD}$

Ambrose et al (33) subsequently compared the efficacy of metronidazole, cotrimoxazole or a combination of the two antibiotics, against placebo in 72 patients with active disease; unfortunately, no benefit was identified at one month following any of the treatment regimens. In 1991, Sutherland et al (34) randomly assigned 105 patients with active $\mathrm{CD}$ to receive placebo, metronidazole at $10 \mathrm{mg} / \mathrm{kg}$ per day or metronidazole at $20 \mathrm{mg} / \mathrm{kg}$ per day. Although metronidazole led to a reduction in patient CDAI scores, particularly in subjects with large rather than small bowel disease, the proportion of patients in clinical remission at the end of the 16-week study was relatively low and similar in the three groups. These disappointing results may have been due to the relatively high dropout rate caused by the side effects experienced by the patients in the high-dose metronidazole group. Indeed, most clinicians now advocate the use of doses that are significantly less than $20 \mathrm{mg} / \mathrm{kg}$ per day to minimize adverse events (35), and most also warn about the risk of peripheral neuropathy to those patients embarking on a prolonged course of the antibiotic (36).

Following the modest results obtained with metronidazole, investigators turned their attention to better tolerated antibiotics with a broader antibacterial spectrum. In 1993, Peppercorn (37) published the results of a small, uncontrolled study demonstrating a clinical response to ciprofloxacin in patients with Crohn's ileitis. After these preliminary findings, Colombel et al (38) carried out a larger, randomized study 
involving 40 patients with mild to moderate disease activity, and found that a six-week course of ciprofloxacin $(1 \mathrm{~g} /$ day $)$ was equally as effective as mesalamine (4 g/day) in inducing disease remission (56\% versus 55\%, respectively). Subsequently, Arnold et al (39) demonstrated that ciprofloxacin (1 g/day for six months), when added to the treatment of a patients with moderately active $\mathrm{CD}$, led to a clinically significant reduction in CDAI scores when compared with placebo.

A number of researchers have assessed the effect of a combination of ciprofloxacin and metronidazole in patients with active CD, but results have been mixed. Prantera et al (40) found that patients with moderately active disease who received a 12-week course of this antibiotic combination achieved clinical remission (46\% remission rate) less often than patients treated with methylprednisolone (63\% remission rate). The same investigators also performed a retrospective evaluation of the use of metronidazole and/or ciprofloxacin and found that complete or partial remission of the disease, as defined by the CDAI score, was approximately $70 \%$ in patients treated with either single or combined therapy (41). In an uncontrolled study, Greenbloom et al (42) demonstrated a similar clinical remission rate $(68 \%)$ in patients with active $\mathrm{CD}$ of the ileum and/or colon who received a 10-week combination of ciprofloxacin and metronidazole; notably, a clinical response occurred in a greater proportion of patients with colonic disease compared with ileal disease alone. More recently, a prospective double-blind study evaluated the use of the same antibiotic combination in patients receiving oral budesonide for ileal CD with or without right-sided colonic involvement (43). Although the overall results showed no improvement in response or remission with the addition of antibiotics, among patients with some involvement of the colon, the proportion achieving remission was higher in patients taking antibiotics (53\%) compared with those taking placebo (25\%).

Other antibiotics have also been evaluated in active $\mathrm{CD}$ because of the frequent side effects requiring discontinuation of therapy observed in up to $20 \%$ of patients receiving ciprofloxacin and/or metronidazole (41). Indeed, individual agents used in antimycobacterial regimens have been assessed. For example, Leiper et al (44) performed an open-label study demonstrating a $48 \%$ remission rate following a four-week course of clarithromycin, with only two of the 25 patients withdrawing due to nonserious side effects. More recently, rifaximin, a rifamycinderived antibiotic with a broad antibacterial spectrum and an excellent safety profile due to very low systemic absorption (45) has proven promising in preliminary studies of patients with mild to moderate (46) and moderate to severe (47) CD, although further large-scale controlled evaluation is required.

\section{Antibiotic therapy in postoperative CD}

Disease recurrence following intestinal resection for active CD is common: one year after ileocolonic anastamosis with clinical recurrence occuring in $20 \%$ to $37 \%$ of patients, and endoscopic recurrence occurring even more quickly, with observed rates between $73 \%$ and $93 \%(48,49)$. The ability of a variety of prophylactic medications (such as aminosalicylates, corticosteroids and purine analogues) to reduce postoperative recurrence has been assessed, with no clear regimen identified (for review see [50]). The observations that disease recurrence is prevented following an ileocolonic anastamosis if the fecal stream is diverted through a proximal loop ileostomy (51), while infusion of intestinal contents into the excluded distal ileal loop leading to the anastamosis rapidly induces inflammatory changes (16), provide indirect evidence that bacteria may play a role in postoperative disease recurrence and also provides a rationale for using prophylactic antibiotics in this setting. Moreover, the association of early disease recurrence with increased concentrations of Escherichia coli and Bacteroides species in the neoterminal ileum of patients following ileocolectomy adds further support to this rationale (19).

Rutgeerts et al $(52,53)$ performed two double-blind, placebo-controlled studies to determine the efficacy of imidazole antibiotics in the prevention of postoperative recurrence of $\mathrm{CD}$. In the first study (52), a three-month course of metronidazole, given immediately following 'curative' ileal resection, reduced symptomatic and endoscopic recurrence rates at one year, with an important trend toward reduced clinical recurrence for as long as 36 months after surgery. In the second study, a one-year course of ornidazole also reduced clinical and endoscopic recurrence rates at one year (53). Notably, more patients in the ornidazole group dropped out because of side effects and further work is required to gauge the optimal dose and duration of treatment required to maximize the efficacy and limit the toxicity of postoperative antibiotics in CD.

\section{Antibiotic therapy in perianal CD}

Antibiotics are established in treatment guidelines for simple and complex fistulizing perianal CD $(54,55)$, although they have not been evaluated for this indication in placebo-controlled trials. However, uncontrolled studies (56-60) and clinical experience support their standing in such guidelines. For example, Bernstein et al (57) reported complete healing of perianal disease in 10 of 18 patients treated with $20 \mathrm{mg} / \mathrm{kg}$ of metronidazole, with subsequent exacerbation of disease on dose reduction in all patients (58). Ciprofloxacin is also widely used together with metronidazole to treat perianal CD (55), although evidence for its efficacy also derives only from small uncontrolled studies. Solomon et al (60), for example, found that this antibiotic combination led to clinical improvement in nine of 14 patients with fistula closure in three of 14 patients (60).

There is some evidence that concomitant use of antibiotics and immunomodulators, such as azathioprine (61) or infliximab (62) may be of mutual benefit in treating perianal CD. Dejaco et al (61) performed a prospective, open-label study to assess the effect of an eight-week course of ciprofloxacin and/or metronidazole as a bridge to azathioprine therapy in 52 patients with perianal fistulas. At week 20, patients who were maintained on azathioprine displayed a higher response rate $(48 \%)$ than those who were not maintained on azathioprine (15\%). West et al (62) recently investigated whether concomitant use of ciprofloxacin enhanced the efficacy of infliximab in patients with perianal fistulas. Twenty-four patients were randomly assigned to receive ciprofloxacin twice daily or placebo for 12 weeks, and all patients additionally received infliximab at weeks 6,8 and 12 . The combination of ciprofloxacin and infliximab (73\% clinical response rate) tended to be more effective than infliximab alone (39\% clinical response rate) at week 18 follow-up.

\section{SUMMARY AND FUTURE DIRECTIONS}

While it is now widely accepted that bacteria play a pathogenic role in the etiology of $\mathrm{CD}$, current evidence supporting the use of antibiotics in active disease is hampered by the lack of welldesigned, adequately powered, placebo-controlled trials. This 
has led to understandable reticence by some clinicians to recommend antibiotics as primary therapy in luminal disease (1). This contrasts with wide acceptance of the use of antibiotics in treating perianal CD $(54,55)$, despite a comparable lack of evidence for their efficacy in this setting. Why such a contradiction exists is unclear. However, based on the literature to date, there does appear to be reasonable, albeit circumstantial evidence that altering the intestinal bacterial milieu, through the use of broad-spectrum antibiotics, is effective in the treatment of active luminal CD. While individual studies have not proven that antibiotic therapy is efficacious, there seems to be a consistent biological effect, particularly in the subgroup of patients with colonic disease $(30,34,42,43)$. Unfortunately, none of the studies have specifically examined this group of patients and none has had sufficient number of patients with colonic disease to definitively test the hypothesis that antibiotics are effective in the treatment of colonic disease. This emphasizes the importance of patient selection or, more correctly, phenotype selection when designing large therapeutic trials in $\mathrm{CD}$. The reason for the differential response of colonic compared with ileal $\mathrm{CD}$ to antibiotic therapy is another question requiring evaluation, but likely relates to differences in enteric flora between the two sites (3).

Classification of patients into different clinical phenotypes for trials of antibiotic therapy may be further enhanced by preemptive assessment of an individual's seroreactivity to microbial components. Mow et al (63) recently provided preliminary data suggesting that $\mathrm{CD}$ patients with predominant serum antibody reactivity toward the bacterial antigens OmpC/I2 had the highest remission rate following treatment with budesonide combined with metronidazole and ciprofloxacin, whereas patients with no immunoreactivity had the lowest rate of response to this combination; by contrast, patients with the OmpC/I2-predominant profile displayed a poor remission rate following budesonide treatment alone. It is

\section{REFERENCES}

1. Wild GE. The role of antibiotics in the management of Crohn's disease. Inflamm Bowel Dis 2004;10:321-3.

2. Shanahan F, Bernstein CN. Antibiotics as a first-line therapy for Crohn's disease: Is there any consensus? Inflamm Bowel Dis 2004;10:324-6.

3. Greenberg GR. Antibiotics should be used as first-line therapy for Crohn's disease. Inflamm Bowel Dis 2004;10:318-20.

4. Sartor RB. Does Mycobacterium avium subspecies paratuberculosis cause Crohn's disease? Gut 2005;54:896-8.

5. Tamboli CP, Neut C, Desreumaux P, Colombel JF. Dysbiosis in inflammatory bowel disease. Gut 2004;53:1-4.

6. Thomas GA, Swift GL, Green JT, et al. Controlled trial of antituberculous chemotherapy in Crohn's disease: A five year follow up study. Gut 1998;42:497-500.

7. Borgaonkar MR, MacIntosh DG, Fardy JM. A meta-analysis of antimycobacterial therapy for Crohn's disease. Am J Gastroenterol 2000;95:725-9.

8. Rath HC, Herfarth HH, Ikeda JS, et al. Normal luminal bacteria, especially Bacteroides species, mediate chronic colitis, gastritis, and arthritis in HLA-B27/human beta2 microglobulin transgenic rats. J Clin Invest 1996;98:945-53.

9. Dianda L, Hanby AM, Wright NA, Sebesteny A, Hayday AC, Owen MJ. T cell receptor-alpha beta-deficient mice fail to develop colitis in the absence of a microbial environment. Am J Pathol 1997;150:91-7.

10. Sellon RK, Tonkonogy S, Schultz M, et al. Resident enteric bacteria are necessary for development of spontaneous colitis and immune system activation in interleukin-10-deficient mice. Infect Immun 1998;66:5224-31.

11. Veltkamp C, Tonkonogy SL, De Jong YP, et al. Continuous stimulation by normal luminal bacteria is essential for the too early to say whether genotypic classification of patients will be of similar value in predicting antibiotic response. However, subgrouping patients according to clinical, serological and genetic markers in all therapeutic trials in CD remains a distinct possibility for the future, with the hope that improved stratification will predict which patients are likely to respond to specific interventions.

For the time being, more fundamental questions still exist regarding the optimal antibiotic regimen and duration of therapy and the place of antimicrobial therapy in the context of concomitant immunomodulating treatments. Information gleaned from animal models of IBD suggest that not all bacterial species have equal activities in inducing gastrointestinal inflammation (8); therefore, it is reasonable to infer that not all antibiotic regimens will be equally effective in treating all groups of patients with $\mathrm{CD}$. While the existing data may point to a role for ciprofloxacin and/or metronidazole in certain clinical settings, these antibiotics have significant side effects at the doses studied and this calls for further assessment of novel, better-tolerated nonabsorbable agents. Clinical experience (3), coupled with limited information from therapeutic trials $(58,61)$, suggest that long-term antibiotic use is required to avoid the disease relapses that typically occur following treatment cessation. Tolerability of long-term treatments again becomes an issue and further work is needed to confirm whether antibiotics can be used to induce remission as a bridge, not only to immunomodulators, but also to probiotics, which may be better tolerated for maintenance of remission.

There are clearly a number of unanswered questions as to the place of antibiotics in the therapeutic armamentarium in $\mathrm{CD}$. While rationale exists for their use, as does preliminary evidence of their efficacy, there is an immediate need for further rigorous multicentre studies into the role of antibiotics in treating active luminal and perianal CD, and their role as prophylactic therapy following surgery.

development and perpetuation of colitis in $\mathrm{Tg}($ epsilon26) mice. Gastroenterology 2001;120:900-13.

12. Panwala CM, Jones JC, Viney JL. A novel model of inflammatory bowel disease: Mice deficient for the multiple drug resistance gene, mdr1a, spontaneously develop colitis. J Immunol 1998;161:5733-44.

13. Madsen KL, Doyle JS, Tavernini MM, Jewell LD, Rennie RP, Fedorak RN. Antibiotic therapy attenuates colitis in interleukin 10 gene-deficient mice. Gastroenterology 2000;118:1094-105.

14. Rath HC, Schultz M, Freitag R, et al. Different subsets of enteric bacteria induce and perpetuate experimental colitis in rats and mice. Infect Immun 2001;69:2277-85.

15. Dieleman LA, Goerres MS, Arends A, et al. Lactobacillus GG prevents recurrence of colitis in HLA-B27 transgenic rats after antibiotic treatment. Gut 2003;52:370-6.

16. D'Haens GR, Geboes K, Peeters M, Baert F, Penninckx F, Rutgeerts P. Early lesions of recurrent Crohn's disease caused by infusion of intestinal contents in excluded ileum. Gastroenterology 1998;114:262-7.

17. Harper PH, Lee EC, Kettlewell MG, Bennett MK, Jewell DP. Role of the faecal stream in the maintenance of Crohn's colitis. Gut 1985;26:279-84.

18. Swidsinski A, Ladhoff A, Pernthaler A, et al. Mucosal flora in inflammatory bowel disease. Gastroenterology 2002;122:44-54.

19. Neut C, Bulois P, Desreumaux P, et al. Changes in the bacterial flora of the neoterminal ileum after ileocolonic resection for Crohn's disease. Am J Gastroenterol 2002;97:939-46.

20. Kleessen B, Kroesen AJ, Buhr HJ, Blaut M. Mucosal and invading bacteria in patients with inflammatory bowel disease compared with controls. Scand J Gastroenterol 2002;37:1034-41.

21. Duchmann R, Kaiser I, Hermann E, Mayet W, Ewe K, Meyer zum Buschenfelde $\mathrm{KH}$. Tolerance exists towards resident intestinal flora 
but is broken in active inflammatory bowel disease (IBD). Clin Exp Immunol 1995;102:448-55.

22. Macpherson A, Khoo UY, Forgacs I, Philpott-Howard J, Bjarnason I. Mucosal antibodies in inflammatory bowel disease are directed against intestinal bacteria. Gut 1996;38:365-75

23. Hugot JP, Chamaillard M, Zouali H, et al. Association of NOD2 leucine-rich repeat variants with susceptibility to Crohn's disease. Nature 2001;411:599-603.

24. Ogura Y, Bonen DK, Inohara N, et al. A frameshift mutation in NOD2 associated with susceptibility to Crohn's disease. Nature 2001;411:603-6.

25. Hisamatsu T, Suzuki M, Reinecker HC, Nadeau WJ, McCormick BA, Podolsky DK. CARD15/NOD2 functions as an antibacterial factor in human intestinal epithelial cells. Gastroenterology 2003;124:993-1000.

26. Isaacs KL, Sartor RB. Treatment of inflammatory bowel disease with antibiotics. Gastroenterol Clin North Am 2004:33:335-45.

27. Williams AC, Galley HF, Watt AM, Webster NR. Differential effects of three antibiotics on $\mathrm{T}$ helper cell cytokine expression. J Antimicrob Chemother 2005;56:502-6

28. Takahashi HK, Iwagaki H, Xue D, et al. Effect of ciprofloxacin-induced prostaglandin E2 on interleukin-18-treated monocytes. Antimicrob Agents Chemother 2005;49:3228-33.

29. Ziglam HM, Daniels I, Finch RG. Immunomodulating activity of rifampicin. J Chemother 2004;16:357-61.

30. Blichfeldt P, Blomhoff JP, Myhre E, Gjone E. Metronidazole in Crohn's disease. A double blind cross-over clinical trial. Scand J Gastroenterol 1978;13:123-7.

31. Rosen A, Ursing B, Alm T, et al. A comparative study of metronidazole and sulfasalazine for active Crohn's disease The cooperative Crohn's disease study in Sweden. I. Design and methodologic considerations. Gastroenterology 1982;83:541-9.

32. Ursing B, Alm T, Barany F, et al. A comparative study of metronidazole and sulfasalazine for active Crohn's disease: The cooperative Crohn's disease study in Sweden. II. Result. Gastroenterology 1982;83:550-62.

33. Ambrose NS, Allan RN, Keighley MR, et al. Antibiotic therapy for treatment in relapse of intestinal Crohn's disease. A prospective randomized study. Dis Colon Rectum 1985;28:81-5.

34. Sutherland L, Singleton J, Sessions J, et al. Double blind, placebo controlled trial of metronidazole in Crohn's disease. Gut 1991;32:1071-5.

35. Carter MJ, Lobo AJ, Travis SP. Guidelines for the management of inflammatory bowel disease in adults. Gut 2004;53(Suppl 5):V1-16.

36. Duffy LF, Daum F, Fisher SE, et al. Peripheral neuropathy in Crohn's disease patients treated with metronidazole. Gastroenterology 1985;88:681-4

37. Peppercorn MA. Is there a role for antibiotics as primary therapy in Crohn's ileitis? J Clin Gastroenterol 1993;17:235-7.

38. Colombel JF, Lemann M, Cassagnou M, et al. A controlled trial comparing ciprofloxacin with mesalazine for the treatment of active Crohn's disease. Groupe d'Etudes Therapeutiques des Affections Inflammatoires Digestives (GETAID). Am J Gastroenterol 1999;94:674-8.

39. Arnold GL, Beaves MR, Pryjdun VO, Mook WJ. Preliminary study of ciprofloxacin in active Crohn's disease. Inflamm Bowel Dis 2002;8:10-5.

40. Prantera C, Zannoni F, Scribano ML, et al. An antibiotic regimen for the treatment of active Crohn's disease: A randomized, controlled clinical trial of metronidazole plus ciprofloxacin. Am J Gastroenterol 1996; $91: 328-32$.

41. Prantera C, Berto E, Scribano ML, Falasco G. Use of antibiotics in the treatment of active Crohn's disease: Experience with metronidazole and ciprofloxacin. Ital J Gastroenterol Hepatol $1998 ; 30: 602-6$
42. Greenbloom SL, Steinhart AH, Greenberg GR. Combination ciprofloxacin and metronidazole for active Crohn's disease. Can J Gastroenterol 1998;12:53-6.

43. Steinhart AH, Feagan BG, Wong CJ, et al. Combined budesonide and antibiotic therapy for active Crohn's disease: A randomized controlled trial. Gastroenterology 2002;123:33-40.

44. Leiper K, Morris AI, Rhodes JM. Open label trial of oral clarithromycin in active Crohn's disease. Aliment Pharmacol Ther 2000;14:801-6.

45. Gionchetti P, Rizzello F, Morselli C, Romagnoli R, Campieri M. Management of inflammatory bowel disease: Does rifaximin offer any promise? Chemotherapy 2005;51 Suppl 1:96-102.

46. Shafran I, Johnson LK. An open-label evaluation of rifaximin in the treatment of active Crohn's disease. Curr Med Res Opin 2005;21:1165-9.

47. Bosworth BP, Scherl E. A novel nonabsorbable antibiotic (rifaximin) in the treatment of moderate to severe Crohn's disease. Gastroenterology 2005;128:576A. (Abst)

48. Rutgeerts P, Geboes K, Vantrappen G, Beyls J, Kerremans R, Hiele M. Predictability of the postoperative course of Crohn's disease. Gastroenterology 1990;99:956-63.

49. Olaison G, Smedh K, Sjodahl R. Natural course of Crohn's disease after ileocolic resection: Endoscopically visualised ileal ulcers preceding symptoms. Gut 1992;33:331-5.

50. Rutgeerts P. Strategies in the prevention of post-operative recurrence in Crohn's disease. Best Pract Res Clin Gastroenterol 2003;17:63-73.

51. Rutgeerts P, Goboes K, Peeters M, et al. Effect of faecal stream diversion on recurrence of Crohn's disease in the neoterminal ileum. Lancet 1991;338:771-4.

52. Rutgeerts P, Hiele M, Geboes K, et al. Controlled trial of metronidazole treatment for prevention of Crohn's recurrence after ileal resection. Gastroenterology 1995;108:1617-21.

53. Rutgeerts P, Van Assche G, Vermeire S, et al. Ornidazole for prophylaxis of postoperative Crohn's disease recurrence: A randomized, double-blind, placebo-controlled trial. Gastroenterology 2005;128:856-61.

54. Sandborn WJ, Fazio VW, Feagan BG, Hanauer SB. AGA technical review on perianal Crohn's disease. Gastroenterology 2003;125:1508-30.

55. Schwartz DA, Herdman CR. Review article: The medical treatment of Crohn's perianal fistulas. Aliment Pharmacol Ther 2004;19:953-67.

56. Ursing B, Kamme C. Metronidazole for Crohn's disease. Lancet 1975;1:775-7.

57. Bernstein LH, Frank MS, Brandt LJ, Boley SJ. Healing of perineal Crohn's disease with metronidazole. Gastroenterology 1980;79:599.

58. Brandt LJ, Bernstein LH, Boley SJ, Frank MS. Metronidazole therapy for perineal Crohn's disease: A follow-up study. Gastroenterology 1982;83:383-7.

59. Jakobovits J, Schuster MM. Metronidazole therapy for Crohn's disease and associated fistulae. Am J Gastroenterol 1984;79:533-40.

60. Solomon M, Mcleod R, O'Conner B, Steinhart AH, Greenberg G, Cohen Z. Combination ciprofloxacin and metronidazole in severe perinanal Crohn's disease. Can J Gastroenterol 1993;7:571-3.

61. Dejaco C, Harrer M, Waldhoer T, Miehsler W, Vogelsang H, Reinisch W. Antibiotics and azathioprine for the treatment of perianal fistulas in Crohn's disease. Aliment Pharmacol Ther 2003; 18:1113-20.

62. West RL, van der Woude CJ, Hansen BE, et al. Clinical and endosonographic effect of ciprofloxacin on the treatment of perianal fistulae in Crohn's disease with infliximab: A double-blind placebocontrolled study. Aliment Pharmacol Ther 2004:20:1329-36.

63. Mow WS, Landers CJ, Steinhart AH, et al. High-level serum antibodies to bacterial antigens are associated with antibiotic-induced clinical remission in Crohn's disease: A pilot study. Dig Dis Sci 2004;49:1280-6 


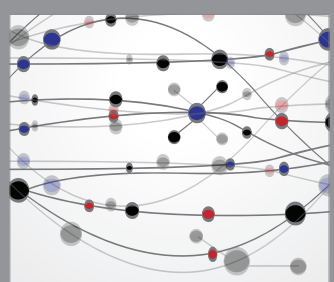

The Scientific World Journal
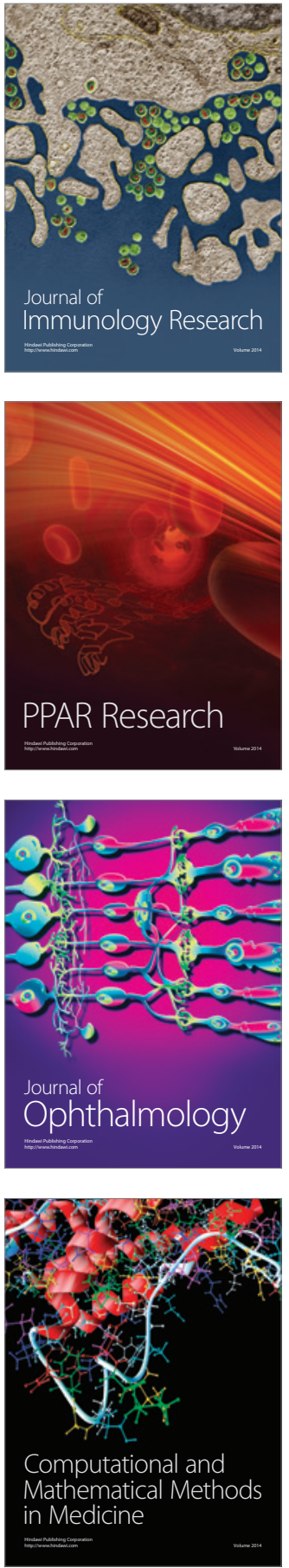

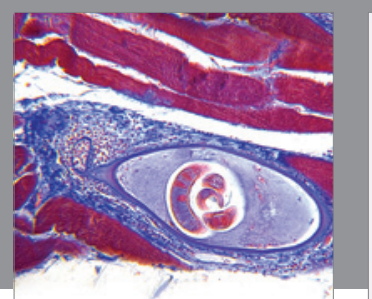

Gastroenterology Research and Practice

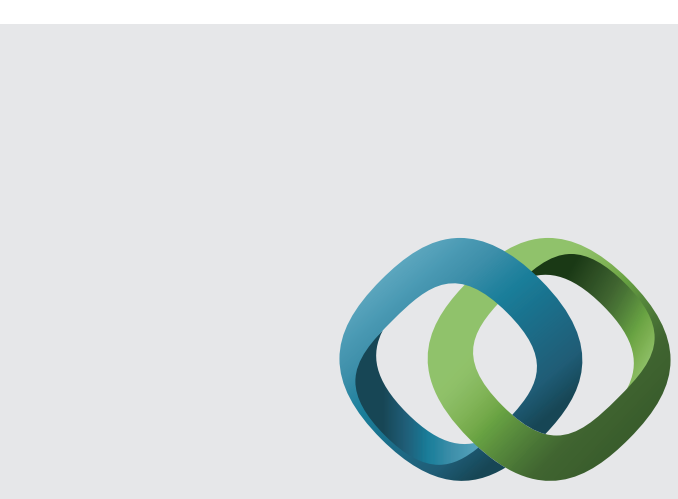

\section{Hindawi}

Submit your manuscripts at

http://www.hindawi.com
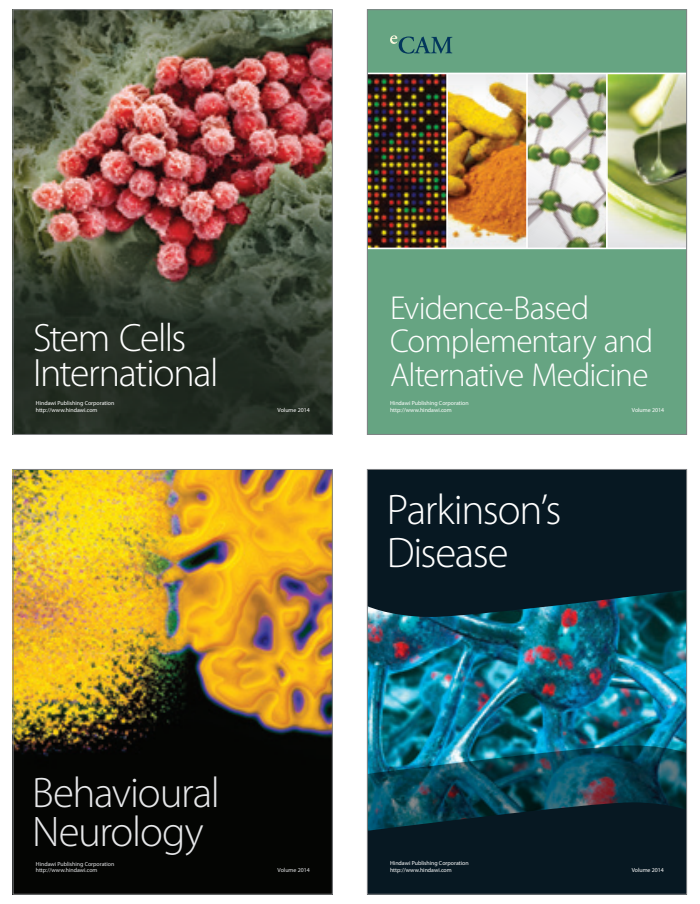
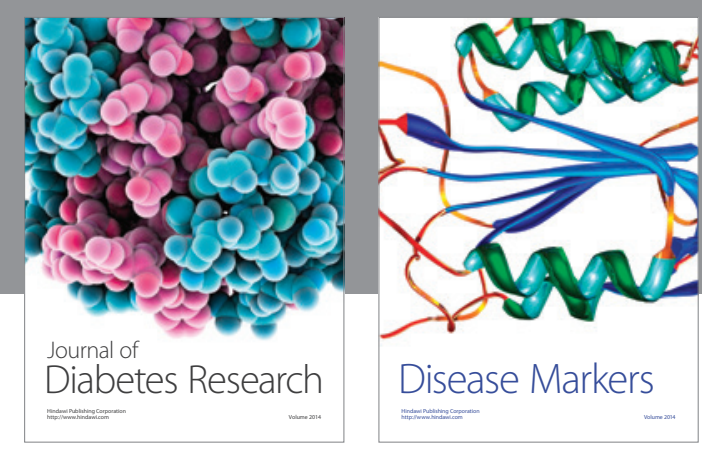

Disease Markers
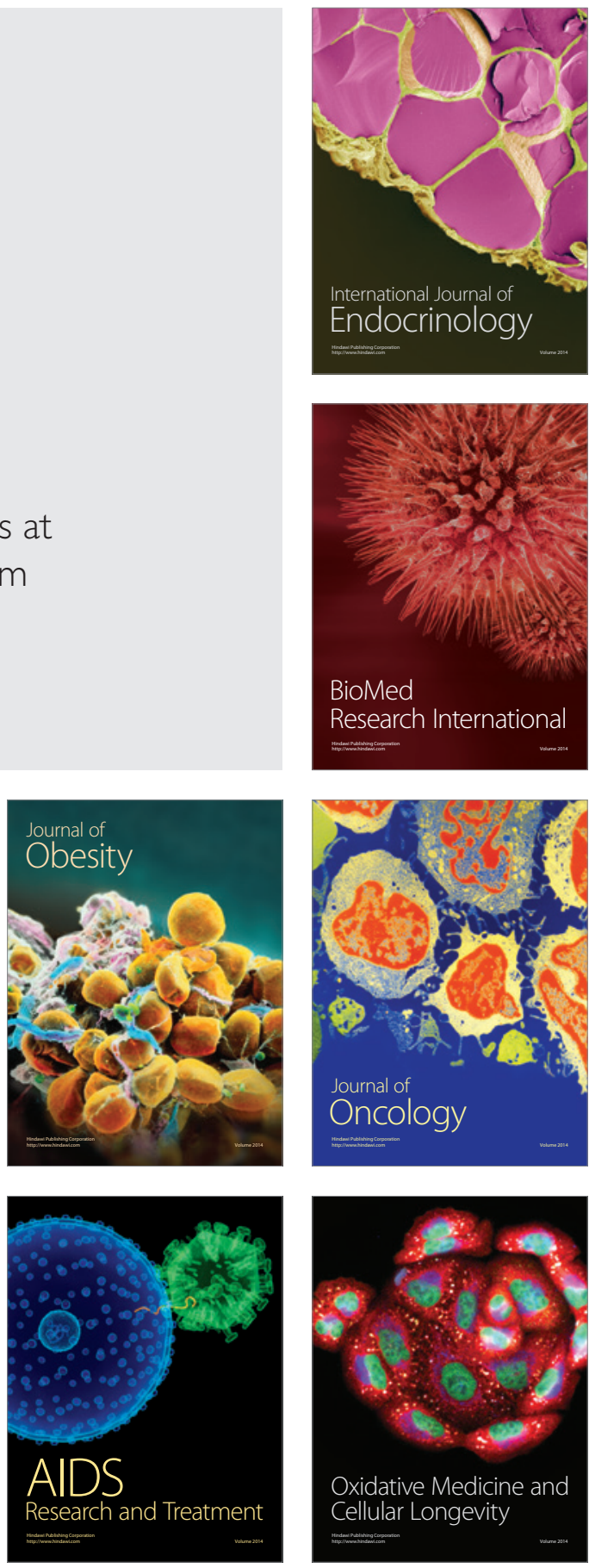